\title{
Intussusception in Neonates: Clinical Characteristics of Eight Cases in a Single Center
}

\author{
Yong-gi Ahn, $\mathrm{MD}^{1}$, Gina Lim, $\mathrm{MD}^{1}$, Eun Ha Hwang, $\mathrm{MD}^{1}$, Ki Won Oh, $\mathrm{MD}^{1}$, and Min Jeng Cho, $\mathrm{MD}^{2}$ \\ Departments of ${ }^{1}$ Pediatrics and ${ }^{2}$ Surgery, Ulsan University Hospital, University of Ulsan College of Medicine, Ulsan, Korea
}

\section{ABSTRACT}

Purpose: Intussusception is the most common cause of bowel obstruction in children; however, it is rarely diagnosed in newborn infants. This study aimed to describe the clinical features of intussusception in newborn infants.

Methods: Medical records of eight patients diagnosed with intussusception during the newborn period at Ulsan University Hospital between March 2007 and March 2020 were retrospectively reviewed.

Results: Among the eight cases, two occurred in the intrauterine period and six occurred in the postnatal period. Intrauterine intussusception presented with symptoms of bowel obstruction within 1 to 2 days after birth, and ileal atresia was diagnosed simultaneously through exploratory laparotomy. All the postnatal patients were extremely low birth weight infants (median gestational age and birth weight: $25^{+6}$ weeks and $745 \mathrm{~g}$, respectively). Four cases were diagnosed preoperatively using abdominal ultrasonography. One patient was diagnosed by exploratory laparotomy because the clinical symptoms were nonspecific and difficult to differentiate from those of necrotizing enterocolitis, a more prevalent complication in preterm infants. The site of intussusception in all six patients was the small bowel. Meckel's diverticulum (one case) and meconium obstruction (two cases) were found to be the lead point.

Conclusion: Neonatal intussusception tends to show different clinical features according to its period of occurrence. Intussusception, especially in preterm infants, has nonspecific clinical features; therefore, clinicians should always be cautious of this disease for its early diagnosis.

Key Words: Intussusception; Infant, newborn; Premature; Intestinal atresia; Enterocolitis, necrotizing; Meconium obstruction

\section{서론}

창자겹침증(intussusception)은 생후 5개월에서 3세 사이 소아에서 발생하는 창자막힘(bowel obstruction)의 가장 흔한 원인이다 ${ }^{1)}$. 하지만 신생아에서 진단되는 경우는 드물어 전체 창자겹 침증의 $1 \%$ 내외를 차지하는 것으로 알려져 있다 ${ }^{2)}$. 신생아 창자겹침증은 태생기에 발생한 경우
Received: 31 August 2020

Revised: 19 October 2020

Accepted: 20 October 2020

Correspondence to: Ki Won Oh, MD

Department of Pediatrics, Ulsan

University Hospital, University of

Ulsan College of Medicine, 877

Bangeojinsunhwan-doro, Dong-gu,

Ulsan 44033, Korea

Tel: +82-52-250-8861

Fax: +82-52-250-8071

E-mail: pentawish@uuh.ulsan.kr

Copyright(c)

By Korean Society of Neonatology.

All right reserved.

This is an Open-Access article distributed under the terms of the Creative Commons At tribution Non-Commercial License (http:// creativecommons.org/licenses/by-nc/4.0), which permits unrestricted non-commercial use, distribution, and reproduction in any medium, provided the original work is pro perly cited. 
와 신생아기에 발생한 경우를 모두 포함하며, 발생 시기에 따라 다 른 임상 양상을 보이는 경향이 있다 ${ }^{3-6)}$. 태생기에 발생한 창자겹침증 은 장폐쇄와 연관되어 진단되는 경우가 많으며, 출생 후 수일 이내 에 창자막힘의 증상이 발생한다 ${ }^{6-10)}$. 신생아기에 발생한 경우는 크 게 두 가지 임상 양상으로 나타날 수 있으며, 그 중 하나는 주로 만삭 아에서 선두(lead point)가 있으면서 회장-결장 부위에 발생하는 경
우와 다른 하나는 재태주령이 어린 미숙아에서 발생하는 경우이다 3-5,11-15). 미숙아에서 발생하는 창자겹침증은 주로 소장 부위에 발생 하며, 괴사성 장염과의 감별이 어려워 진단과 치료가 지연되는 경우 가 많은 것으로 알려져 있다-5,11-18) 이번 연구에서는 단일 병원에서 경험한 신생아 창자겹침증의 임상 양상을 살펴보고자 하였다.

Table 1. Demographics and Laboratory Findings in Eight Patients with Neonatal Intussusception

\begin{tabular}{|c|c|c|c|c|c|c|c|c|}
\hline Variable & Case 1 & Case 2 & Case 3 & Case 4 & Case 5 & Case 6 & Case 7 & Case 8 \\
\hline GA (wk) & $37^{+5}$ & $25^{+1}$ & 25 & $38^{+1}$ & $26^{+6}$ & $26^{+4}$ & $23^{+6}$ & 28 \\
\hline BW (g) & 2,840 & 730 & 760 & 3,450 & 980 & 680 & 660 & 980 \\
\hline Sex & $\mathrm{F}$ & $\mathrm{F}$ & M & M & $\mathrm{F}$ & M & $\mathrm{F}$ & M \\
\hline $1-\min$ AS & 8 & 4 & 2 & 8 & 3 & 4 & 2 & 6 \\
\hline 5 -min AS & 9 & 7 & 5 & 9 & 5 & 7 & 3 & 7 \\
\hline $\begin{array}{l}\text { Maternal medical } \\
\text { history }\end{array}$ & NS & Hypothyroidism & NS & Gestational DM & $\begin{array}{c}\text { Hypothyroidism, } \\
\text { hypertension }\end{array}$ & $\begin{array}{l}\text { Pre-eclamsia, } \\
\text { CIN of cervix }\end{array}$ & NS & Hyperthyroidism \\
\hline Platelets $\left(\times 10^{3} / \mu \mathrm{L}\right)$ & 454 & 307 & 58 & 314 & 159 & 208 & 247 & 86 \\
\hline $\mathrm{WBC}\left(\times 10^{3} / \mu \mathrm{L}\right)$ & 22.250 & 11.210 & 11.600 & 10.460 & 7.530 & 15.390 & 78.430 & 11.570 \\
\hline Hematocrit (\%) & 43 & 29 & 26 & 37 & 27 & 25 & 27 & 29 \\
\hline $\mathrm{CRP}(\mathrm{mg} / \mathrm{dL})$ & 0.07 & $<0.024$ & 9.5 & 0.05 & 0.05 & 0.01 & 0.01 & 7.0 \\
\hline Hypothyroidism & - & $\stackrel{+}{+}$ & - & NA & - & $\stackrel{+}{\stackrel{+}{\text { Medication (+) }}}$ & $\stackrel{+}{+}$ & - \\
\hline
\end{tabular}

Abbreviations: GA, gestational age; BW, birth weight; AS, Apgar score; NS, nonspecific; DM, diabetes mellitus; CIN, cervical intraepithelial neoplasia; WBC, white blood cell; CRP, C-reactive protein; NA, not applicable.

Table 2. Clinical and Radiologic Characteristics of Eight Patients with Neonatal Intussusception

\begin{tabular}{|c|c|c|c|c|c|c|c|c|}
\hline Variable & Case 1 & Case 2 & Case 3 & Case 4 & Case 5 & Case 6 & Case 7 & Case 8 \\
\hline PMA at diagnosis (wk) & 38 & $27^{+1}$ & $34^{+5}$ & $38^{+3}$ & $32^{+3}$ & $28^{+4}$ & $26^{+5}$ & $34^{+5}$ \\
\hline Age at diagnosis (d) & 3 & 15 & 71 & 3 & 40 & 15 & 21 & 48 \\
\hline RDS/MV & - & + & + & - & + & + & + & + \\
\hline PDA & - & - & + & - & - & + & + & + \\
\hline Hypotension & - & - & + & - & - & - & + & - \\
\hline UAC duration (d) & 0 & 7 & 7 & 0 & 7 & 7 & 8 & 1 \\
\hline UVC duration (d) & 0 & 7 & 12 & 0 & 1 & 7 & 8 & 8 \\
\hline Plain film & $\begin{array}{l}\text { Dilated bowel } \\
\text { loops }\end{array}$ & UR & $\begin{array}{l}\text { Fixed bowel } \\
\text { loops }\end{array}$ & $\begin{array}{l}\text { Dilated bowel } \\
\text { loops }\end{array}$ & $\begin{array}{l}\text { Dilated bowel } \\
\text { loops }\end{array}$ & $\begin{array}{l}\text { Dilated bowel } \\
\text { loops }\end{array}$ & Free gas & $\begin{array}{l}\text { Dilated bowel } \\
\text { loops }\end{array}$ \\
\hline Colon study & Microcolon & NA & NA & NA & NA & UR & NA & NA \\
\hline Ultrasonography & NA & SB Intu & $\begin{array}{l}\text { SB wall } \\
\text { thickening }\end{array}$ & SB obstruction & SB Intu & SB Intu & NA & SB Intu \\
\hline Location & Ileo-ileal & SB & Jejuno-jejunal & Ileo-ileal & SB & Ileo-ileal & Ileo-ileal & Ileo-ileal \\
\hline Perforation & - & - & - & - & Unknown & - & + & - \\
\hline $\begin{array}{l}\text { Lead point or associated } \\
\text { problem }\end{array}$ & $\begin{array}{l}\text { Intestinal } \\
\text { atresia }\end{array}$ & $\begin{array}{l}\text { Meconium } \\
\text { plug }\end{array}$ & NEC & $\begin{array}{l}\text { Intestinal } \\
\text { atresia }\end{array}$ & Unknown & $\begin{array}{l}\text { Meconium } \\
\text { plug }\end{array}$ & - & $\begin{array}{c}\text { Meckel's } \\
\text { diverticulum }\end{array}$ \\
\hline Type of repair & SB. R\&A & Ileostomy & Jejunostomy & SB R\&A & Unknown & SB R\&A & Ileostomy & SB R\&A \\
\hline Outcome & Survived & Survived & Unknown & Survived & Unknown & Survived & Survived & Survived \\
\hline
\end{tabular}

Abbreviations: PMA, postmenstrual age; RDS, respiratory distress syndrome; MV, mechanical ventilation; PDA, patent ductus arteriosus; UAC, umbilical artery catheterization; UVC, umbilical vein catheterization; UR, unremarkable; NA, not applicable; SB, small bowel; Intu., intussusception; NEC, necrotizing enterocolitis; R\&A, resection and anastomosis. 


\section{대상 및 방법}

2007년 3월부터 2020년 3월까지 울산대학교병원에서 창자겹침 증으로 진단된 15 세 이하의 소아 환아 중 신생아 시기에 진단된 환 아들의 의무기록을 후향적으로 분석하였다. 신생아의 인구학적 특 성으로는 재태주령, 출생체중, 성별, 분만 형태, 1 분 및 5 분 아프가 점수, 산모력, 태변 배출 시기, 수유 시작 시기 등에 관한 정보를 조 사하였고, 창자겹침증과 관련해서는 동반된 위험요인, 진단 시기, 혈액검사 소견, 영상검사 소견, 수술 소견, 입원 기간, 치료 결과 등 에 관하여 조사하였다(Tables 1,2).

이번 연구에서 신생아 창자겹칩증을 시기적으로 분류함에 있어, 수술적 소견에서 창자겹침증과 함께 장폐쇄가 동반되는 소견을 보 인 경우 태생기에 발생한 것으로 정의하였고, 그 외의 경우는 신생 아기에 발생한 것으로 정의하였다. 갑상선 기능저하증은 갑상선 자 극 호르몬 수치가 $20 \mu \mathrm{IU} / \mathrm{mL}$ 을 초과하고 유리 T4 수치가 정상 범주 $(0.8-1.7 \mathrm{ng} / \mathrm{dL})$ 미만이거나, 갑상선 자극 호르몬 수치가 $40 \mu \mathrm{IU} /$ $\mathrm{mL}$ 을 초과하는 경우로 정의하였다. 복부 초음파는 Philips IU22 ultrasound system (Philips, Amsterdam, the Netherlands) 장비를 사 용하여 소아영상전문의에 의해 시행되었다.

본 연구는 울산대학교병원 의학연구심의위원회(Institutional Review Board, IRB)로부터 승인받았고 동의서는 면제되었다(IRB No. 2020-05-004).

\section{결과}

연구 기간 중 본원에서 창자겹침증으로 진단된 총 685 명의 소아 환자 중 신생아 시기에 진단된 환아는 8 명(1.2\%)이었다. 태아기에 발생한 경우는 2 명이었으며, 재태주령은 각각 38 주 1 일, 37 주 5 일로 만삭아였다. 타원에서 출생 후 한 명은 수유 진행 부진과 담즙성 구 토로, 다른 한 명은 복부 팽만으로 전원되었다. 영상검사에서 소장 폐쇄가 의심되어 탐색개복술을 시행하였으며, 2 명 모두 회장 폐쇄 와 함께 회장-회장 창자겹침증이 발견되었고, 수술 후 특별한 합병 증 없이 퇴원하였다.

신생아기에 발생한 경우는 6명이었으며, 이 중 5명은 재태주령 28 주 미만의 극단적 미숙아였고, 6 명 모두 $1,000 \mathrm{~g}$ 미만의 초극소저체 중 출생아에 해당하였다. 재태주령과 출생체중의 중앙값은 각각 25 주 6 일, $745 \mathrm{~g}$ 이었으며, 성별로는 남아와 여아가 각각 3 명이었다. 창 자겹침증이 진단된 시기의 중앙값은 출생 후 30.5 일, 월경 후 연령으 로 33 주 3.5 일이었다. 모든 환아가 신생아 호흡곤란증후군으로 기 계환기 요법을 시행 받았으며, 6 명 중 4 명은 동맥관개존증으로 약물 적 또는 수술적 치료를 받았다. 진단 당시에 3 명의 환아는 갑상선 기 능저하증 소견을 보였고, 이 중 2 명은 약물치료를 필요하였고, 1 명
은 약물치료 없이 추적검사에서 자연 회복되었다. 단순 복부 방사선 사진에서 6명 중 4명에서 전반적으로 확장된 장 루프(bowel loop) 소견을 보였고, 1명에서 유리가스(free air) 소견을 보였으며 나머지 1 명은 특이 소견이 없었다. 대장 조영술은 1 명에서 시행되었으나 특 이사항이 관찰되지 않았고, 초음파검사를 시행하였던 5명 중 4 명에 서 소장 창자겹침증이 진단되었다(Figure 1). 전원을 간 1 명을 제외 한 5 명의 환아는 개복술을 시행 받았으며, 공장-공장 창자겹침증이 1 명, 회장-회장 창자겹침증이 3 명이었다(Figure 2). 나머지 1명은 수 술 전에 창자겹침증이 자연 정복되어 수술 소견에서는 관찰되지 않 았으며 태변 마개(meconium plug)가 있어 제거해주었다. 창자겹침 증의 선두로 멕켈 게실이 1례, 태변 막힘(meconium obstruction)과 연관되는 경우가 2 례였다. 전원을 간 2 명을 제외한 나머지 4 명은 수 술 후 특별한 합병증 없이 퇴원하였다.

대표적인 증례들의 세부적인 임상 양상은 다음과 같다.

\section{1. 증례 1}

재태주령 37 주 5일, $2,840 \mathrm{~g}$ 으로 출생한 여아로 생후 2 일째 복부 팽만을 주소로 타원에서 전원되었다. 산전 초음파검사에서 특이사

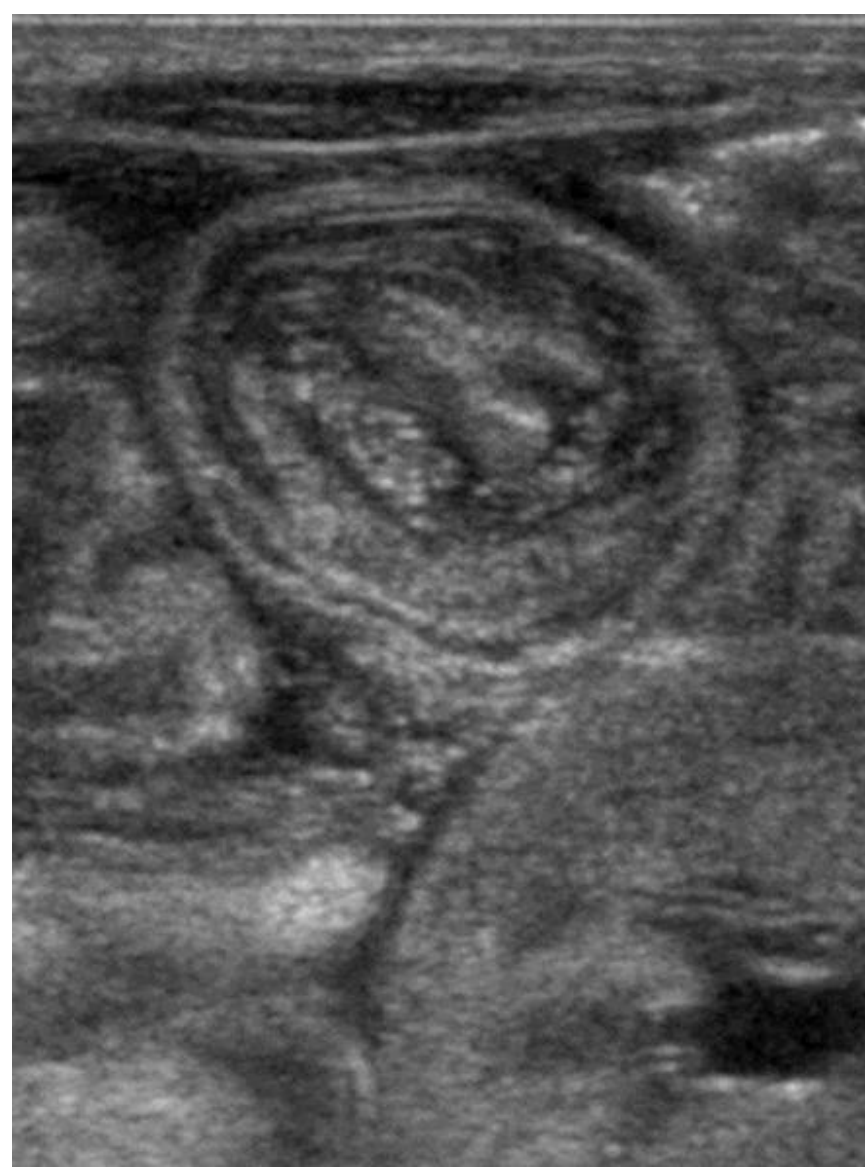

Figure 1. Abdominal ultrasonography of Case 5 demonstrating the characteristic target sign of intussusception. 


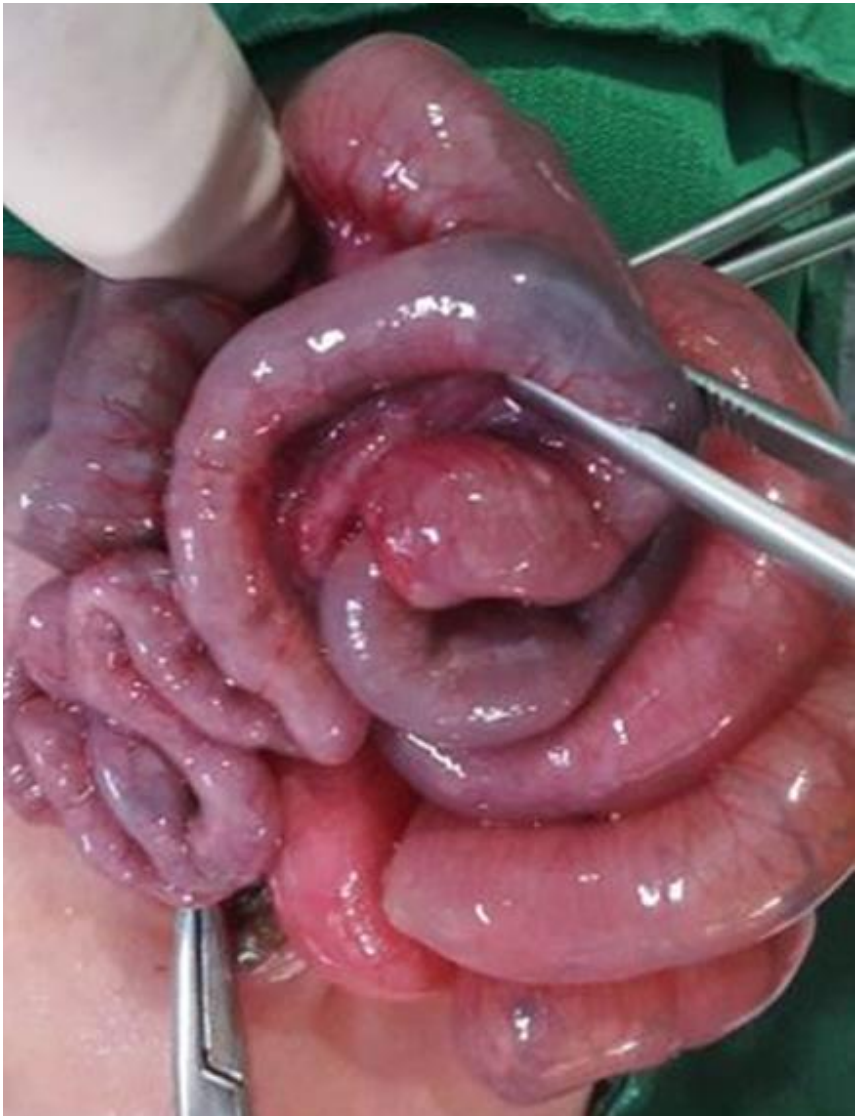

Figure 2. Intraoperative photography of Case 6 showing ileo-ileal intussusception.

항은 없었으며, 출생 후 수유는 10-20 mL를 6차례 진행하였고, 출 생 후 24 시간 내에 태변 배출이 있었다. 단순 복부 방사선 사진상 현 저히 확장된 장 루프들이 관찰되었고(Figure $3 \mathrm{~A}$ ), 가스트로그라핀 (gastrografin)을 이용한 대장 조영술에서 소결장(microcolon) 소견 이 관찰되었다(Figure $3 \mathrm{~B}$ ).

소장 폐쇄를 의심하여 탐색개복술을 시행하였고, 돌막창자판막 상방 $8 \mathrm{~cm}$ 부위에서 회장 폐쇄 소견과 폐쇄 부위에서 인접한 하부에 서 $2 \mathrm{~cm}$ 가량의 창자겹침증 소견이 관찰되었다(Figure $3 \mathrm{C}, \mathrm{D}$ ). 이상 소견이 있는 양쪽 끝부분을 절제 후 단단문합술을 시행하였으며, 수 술 후 특별한 합병증 없이 수유 진행 양호하여 퇴원하였다.

\section{2. 증례 2}

재태주령 25주 1 일, $730 \mathrm{~g}$ 으로 조기 진통이 조절되지 않아 질식 분만을 통해 출생한 여아로, 신생아 호흡곤란 증후군으로 폐계면활 성제 투여와 3 일간의 기계환기 요법을 시행 받았다. 생후 2주째 시 행한 갑상선 기능검사에서 갑상선 기능저하증 소견이 관찰되었으 나 생후 4 주째 추적검사에서는 자연적으로 정상화되었다. 태변 배 출은 생후 24 시간 이내에 관찰되었고, 생후 3 일째 영양 수유를 시작 하여 생후 13 일째 $70 \mathrm{~mL} / \mathrm{kg} / \mathrm{day}$ 까지 진행되었다. 생후 15 일째 비위

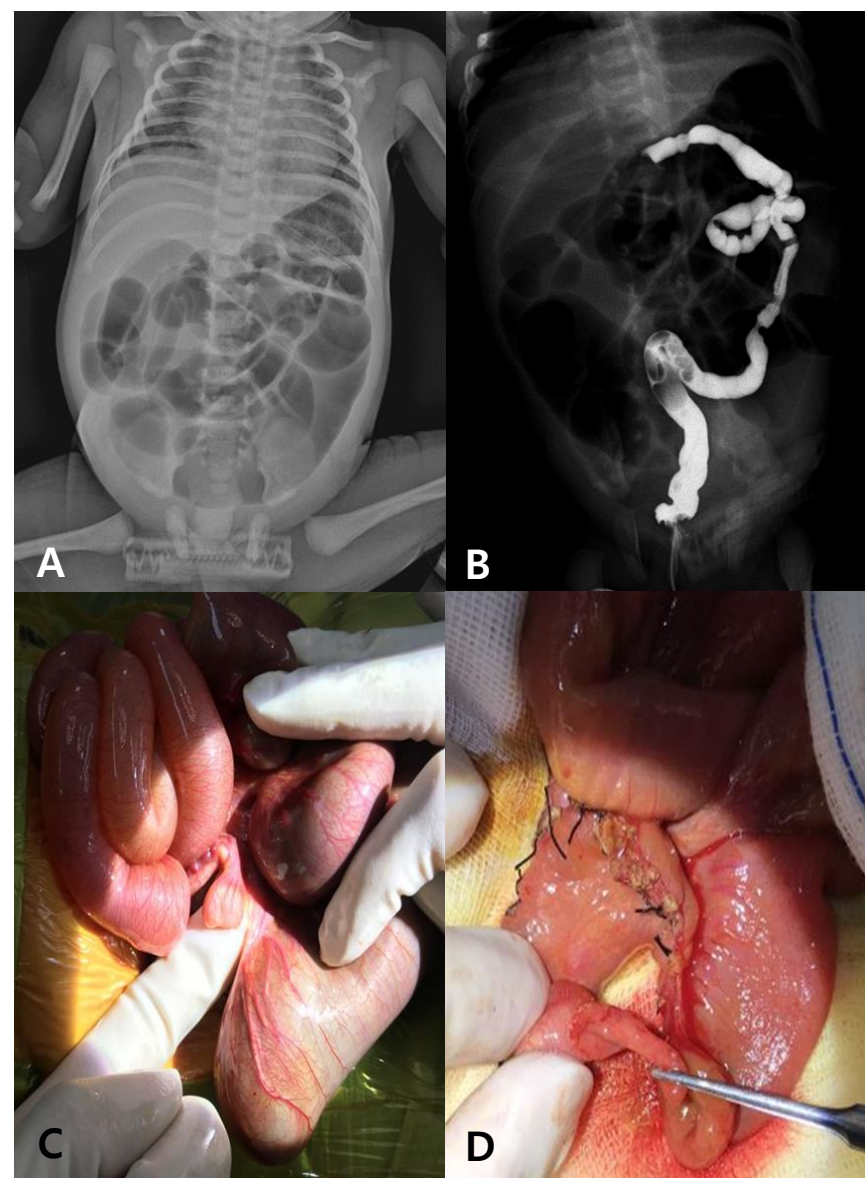

Figure 3. Imaging studies and intraoperative photographs of Case 1. (A) Plain abdominal radiograph showing diffuse dilated bowel loops. (B) Colon study demonstrating microcolon. (C, D) Intraoperative photographs showing a markedly dilated proximal small bowel loop, an atretic distal intestinal loop, and an ileoileal intussusception.

관을 통한 수유 중 산소포화도가 반복적으로 감소되어 복부 초음파 검사를 시행하였으며, 회장-회장 창자겹칩증이 진단되었다. 색조도 플러검사에서 장관으로의 혈행 흐름이 원활하여 경과 관찰하였으 며, 3 일 후 시행한 추적검사에서 자연 소실되었음을 확인하였다. 생 후 22 일째 시행한 재검사에서 소장부위에 다중 창자겹칩증이 관찰 되었으나, 생후 29일째 복부 초음파검사에서는 다시 자연 소실되었 다. 이후 반복적으로 수유를 시도하였으나 진행이 원활하지 않았고 복부 팽만 및 단순 복부 방사선검사상 장관 내에 광범위한 공기 확 장 소견이 지속되었다.

생후 42 일째 복부 초음파검사에서 장운동의 감소와 회장 말단 부 위에 분변 매복(fecal impaction) 소견이 관찰되어 생후 45 일째 탐색 개복술을 시행하였다. 수술 소견으로는 돌막창자판막으로부터 10 $\mathrm{cm}$ 상방 회장부 말단에서부터 대장 일부까지 딱딱한 태변으로 가득 차 있었으며(Figure 4), 창자겹칩증 소견이나 장천공은 관찰되지 않 았다. 회장루를 만들었고, 생후 154 일째 장루 복원술을 시행하였으 


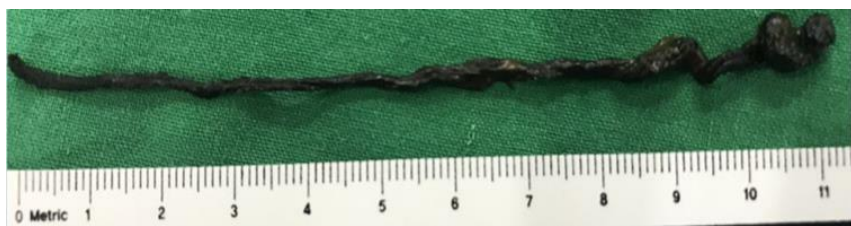

MONAMISKIN LINER

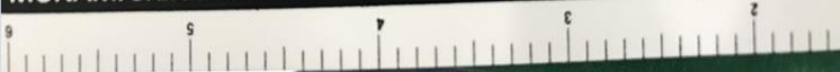

Figure 4. Meconium plug passed by Case 2 .

며, 생후 169 일째 체중 $5.1 \mathrm{~kg}$ 으로 퇴원하였다.

\section{3. 증례 3}

재태주령 25 주, $760 \mathrm{~g}$ 으로 산모 자궁경관무력증으로 인해 질식분 만을 통해 출생한 남아로, 1 분, 5 분 아프가 점수는 각각 2점, 5 점이었 다. 출생 직후 신생아 호흡곤란 증후군으로 폐계면활성제 투여와 기 계환기 요법을 시행하였으며, 생후 34 일째 기계환기에서 이탈 후 비 강 지속 양압 환기요법으로 변경하였다. 출생 첫날부터 동맥관 폐쇄 를 위해 예방적으로 인도메타신을 투여하였으나 폐쇄되지 않아 생 후 25 일째 수술적 치료를 시행하였다. 생후 2 일째 태변 배출이 있었 으며, 생후 7 일째 영양 수유를 시작하였으나 담즙성 위장 저류와 복 부 팽만으로 인하여 금식이 반복되었다. 생후 48 일째 비강 지속 양 압 환기요법 치료 중 산소포화도 감소 및 서맥이 반복되어 기계환기 요법을 재시행하였으며, 혈소판 감소증 및 C-반응단백의 상승, 저혈 압 소견을 보여 패혈증 및 괴사성 장염 의심하에 금식, 광범위 항생 제 및 승압제 치료를 시작하였다.

생후 59일째 칸디다 패혈증으로 항진균제 치료를 시작하였으며, 복부 팽만이 지속되고 단순 복부 방사선 사진에서 고정된 장 루프 가 의심되었다. 복부 초음파검사를 시행하였으나 소장 벽의 두께 가 두꺼운 소견 외에 다른 이상 소견은 없었다. 내과적 치료를 지속 하였으나 환아의 상태가 호전되지 않아 생후 71 일째 시험적 개복술 을 시행하였으며, 공장부위에 창자겹침증이 관찰되어 공장루를 만 들었다. 술 후 34 일째 완전 경관 수유가 가능하였으나, 수술 부위 상 처 감염 및 미숙아망막증 치료를 위해 생후 113 일째 타원으로 전원 되었다.

\section{고찰}

신생아 창자겹침증은 매우 드물어 전체 신생아 창자막힘의 $3 \%$ 정 도를 차지하는 것으로 알려져 있다 ${ }^{19}$. Rachelson 등ํ은 이전 150년 간의 문헌 고찰을 통해 전체 창자겹침증 중 신생아 창자겹침증이 차 지하는 빈도는 $0.3 \%$ 에 불과한 것으로 보고하였으며, Wang 등3)은 단일 병원에서 12 년간의 연구를 통해 소아 창자겹침증 중 $1.3 \%$ 가 신
생아에서 진단된 것으로 보고하였다. 본원에서 최근 13 년간 소아에서 진단된 창자겹침증 중 신생아에서 진단된 경우는 $1.2 \%$ 로 Wang 등 ${ }^{3)}$ 의 연구와 비슷한 빈도로 발생하였고, 지금까지 국내 단일 병원 연 구로는 가장 많은 증례 보고에 해당한다.

신생아 창자겹침증은 태생기에 발생한 경우와 신생아기에 발생 한 경우를 모두 포함한다. 태생기에 발생한 경우 산전에 진단되는 경우는 매우 드물며, 대부분은 출생 후 수시간에서 수일 내에 창자 막힘 증상이 나타나 탐색개복술 도중에 진단되는 경우가 빈번하다. 주로는 만삭아에서 발생한 보고들이 많으며, 흔히 장폐쇄와 동반되 어 발견된다 ${ }^{3-10)}$. 이 경우 전형적인 장폐쇄와는 달리 50\%-75\%에서 출생 후 정상적인 태변 배출이 일어나며, 결장의 크기가 거의 정상 에 가까운 경우가 많아 출생 시기에 근접하여 발생하는 것으로 추정 되고 있닥. 이번 연구에서도 태생기에 발생한 창자겹침증 환아 2명 모두 태변 배출이 24 시간 이내에 있었으며, 1 명에게서 시행된 대장 조영술에서는 소결장 소견이 확인되었다.

신생아기에 발생한 창자겹침증은 재태주령에 따라 상이한 임상 양상을 나타내는 것으로 알려져 있다. 만삭아에서 발생하는 창자겹 침증에서는 선두가 발견되는 빈도가 높으며, 대부분 결장 부분을 침 범하므로 복부 초음파검사를 포함한 영상검사를 통해 진단되는 경 우가 많으나 이번 연구에서는 해당 증례가 없었다.

이번 연구에서 신생아기에 발생한 창자겹침증은 모두 초극소저 체중 출생아에서 발생하였다. 미숙아에서 창자겹침증이 발생하는 경우는 매우 드문 것으로 알려져 있으나, 재태주령이 어린 미숙아 의 초기 생존율이 증가하면서 발생 빈도가 증가하는 것으로 추정된 다. 연구 기간 동안 본원에서 치료한 출생체중 $1,500 \mathrm{~g}$ 미만의 극소 저체중 출생아는 558 명이었으며, 이 중 2 단계 이상의 괴사성 장염이 발생한 환아는 23 명(4.1\%)이었고, 창자겹침증의 발생 빈도는 $1.1 \%$ 에 해당하였다.

미숙아에서 발생하는 창자겹침증의 발생 위치는 만삭아 또는 다 른 소아 호발 연령과는 달리 주로 소장 부위에서 발생하는 것으로 알려져 있다. Martinez Biarge 등 ${ }^{11}$ 에 따르면 미숙아에서 창자겹침 증은 91.6\%가 회장-회장 또는 공장 부위에서 발생했다고 보고하였 으며 이번 연구에서도 6 명 모두 소장 창자겹침증에 해당하였다.

만삭아와 달리 미숙아에서는 단지 8.6\%에서만 폴립, 태변 마개, 멕켈 게실과 같은 선두가 발견되어 상당수의 예에서는 명확한 병인 이 밝혀지지 않고 있다 ${ }^{12)}$. Ueki 등근 저산소 사례(hypoxic event) 가 신생아 후기에 발생하는 창자겹침증의 중요한 병인으로 작용하 는 것으로 제시하였으며, Martinez Biarge 등1)은 미숙아 24명(평균 재태주령 27.8 주, 출생체중 $1,048 \mathrm{~g}$ )을 대상으로 한 문헌고찰을 통 해 흔한 주산기 위험 요소로 신생아 호흡곤란증후군, 동맥관개존증, 저산소증, 저혈압, 제대도관 삽입 등을 언급하였다. 장관의 저관류 와 허혈은 장관의 정체와 운동성 저하를 초래하며 이후 초기 또는 회복기에 과다한 연동운동이 발생하여 기능적인 선두로서 작용하 
는 것으로 추정하고 있다 ${ }^{16,20,21)}$. 우리 증례에서는 6명 모두 신생아 호흡곤란증후군으로 기계환기 요법을 시행 받았으며, 4 명이 동맥 관개존증으로 약물 또는 수술적 치료를 받았다. 선두가 밝혀진 경 우로는 멕켈 게실이 1 례, 태변 막힘과의 연관성이 있는 경우가 2 례 에 해당하였다.

미숙아에서 발생하는 창자겹침증은 괴사성 장염과 임상 증상이 매우 흡사하여 임상의로서 두 질환을 감별하는 것은 아주 어려운 과 제이다. 이는 이전 연구들에서도 잘 나타나 창자겹침증으로 진단된 24 명의 미숙아 중 19 명이 수술 전 진단으로 괴사성 장염이 우선적으 로 고려되었으며 ${ }^{11}$, 이번 증례 3 과 같이 괴사성 장염과 창자겹침증 이 함께 진단된 경우도 있었다 ${ }^{11,12)}$. 이로 인해 증상에서부터 최종 진 단에 이르기까지 평균 9.5일 정도 지연되었으며, 탐색개복술 또는 사후 부검을 통해 비로소 진단되는 경우가 빈번한 것으로 보고된 바 있다, ${ }^{3,1,12)}$. Wang 등3)은 괴사성 장염이 의심되는 환아에서 통상적인 자연 경과에 비해 더 안정된 경과를 보일 경우, 위장관 증상 외에 전 신 증상이 경미할 경우 반드시 창자겹침증을 고려하여야 한다고 제 안하였다. 따라서 임상의로서는 미숙아에서 괴사성 장염이 의심될 경우 창자겹침증에 대하여도 염두에 두고 접근하는 것이 창자겹침 증을 조기에 진단할 수 있는 가장 중요한 요소로 판단된다.

괴사성 장염 외에 미숙아에서 발생하는 중요한 위장관 합병증 중 하나로 자발성 장천공을 들 수 있다. Tadkinlar 등 ${ }^{17)}$ 은 미숙아에서 생후 1-2주 경에 창자겹침증에 동반되어 장천공이 발생할 경우 자 발성 장천공과 감별하기가 쉽지 않다고 보고한 바 있다. 이번 연구 중 증례 7 의 경우 생후 3 주 경에 단순 복부 방사선검사에서 유리가 스가 발견되어 자발성 장천공을 염두에 두고 탐색개복술을 시행하 였으며 예상치 않게 창자겹침증이 진단되었다.

이번 연구에서 증례 2,6 의 경우에는 태변 막힘과 관련되어 창자 겹침증이 발생한 것으로 판단되었다. 초극소저체중 출생아의 경우 장운동이 감소해 있으며, 괴사성 장염에 대한 염려로 금식이 반복되 고 이로 인해 태변의 배출이 원활하게 이루어지지 못하게 됨에 따라 태변 막힘이 발생하여 장중첩증이 발생하는 것으로 추정된다 ${ }^{22-24)}$. 그 외 갑상선 기능저하증도 장운동에 영향을 끼칠 수 있는 요인으 로 생각된다.

미숙아에서 발생한 창자겹침증의 영상검사 소견에 관한 연구에 따르면, 단순 복부 방사선 사진에서는 확장된 장 루프 외에 특징적 인 소견은 없는 것으로 알려져 있다 ${ }^{11-13,15)}$. 또한 미숙아의 창자겹침 증의 호발 위치는 주로 소장이므로 조영제를 이용한 대장 조영술은 진단에 유용하지 않은 것으로 보고되고 있으며, 특히 시술 도중 장 천공의 위험성이 있으므로 치료 목적으로는 시행하지 않는 것이 권 고된다 ${ }^{11,12,15)}$. 창자겹침증의 진단에 있어 초음파검사는 가장 유용한 도구로 알려져 있으나 Avansino 등리에 따르면 초음파검사를 시행 하였던 7 명의 미숙아 중 1 명에서만 진단이 가능하였다. 이처럼 미 숙아에서 초음파로 진단이 어려운 이유로는 우측으로 위치하기 쉬
운 구불결장(sigmoid colon) 및 공기로 팽창한 소장으로 인한 것으 로 추정된다 ${ }^{20)}$. 하지만 최근 논문들에서는 미숙아에서도 초음파검 사를 통해 창자겹침증으로 진단되는 예들이 다수 보고되고 있으며 25-27), 이번 연구에서도 초음파검사를 시행하였던 5명의 환자 중 4 명 에서 진단할 수 있었다.

일반적으로 창자겹침증에 대한 치료로는 방사선 투시 하에 공기 나 바륨을 주입하거나 초음파 유도 하에 식염수를 관장하여 정복하 는 것을 우선적으로 시행한다 ${ }^{1}$. 특히 소장 창자겹침증의 경우 자연 정복되는 경우가 빈번하여, 병적인 선두가 없고, 임상 증상의 기간 이 짧으며, 창자겹침 부위의 길이가 짧고, 혈류 흐름이 충분하며, 일 반 상태가 안정되어 있는 경우는 주의 깊게 관찰하면서 자연 정복을 기대해 볼 수 있는 것으로 알려져 있다 ${ }^{28,29)}$. 하지만 지금까지 발표된 미숙아 창자겹침증의 연구에 따르면, 비록 Ueki 등희 의 연구나 본 연 구의 증례 2 처럼 자연 정복되는 사례가 보고된 바 있으나 대부분의 경우 수술적 치료를 필요로 하였다. 수술 후 재발은 드문 것으로 알 려져 있으며 창자겹침증 자체보다는 미숙아에 동반된 여러 합병증 에 따라 예후가 결정되므로 수술적 치료에 발전이 있음에도 불구하 고 사망을 피할 수 없는 경우가 발생하는 것으로 보고된 바 있단) 이번 연구에서도 수술한 5 명 중 2 명은 단단문합술을 시행하였으나, 장천공이 발생한 경우, 전반적인 장 상태가 불량한 경우, 장운동이 감소하였던 환아에서는 일시적인 장루술을 시행하였다.

결론적으로 신생아 창자겹침증 중 태생기에 발생한 경우는 출생 후 수일 이내에 창자막힘 증상이 나타나므로 탐색개복술을 통해 조 기에 진단과 치료가 용이하였다. 반면 미숙아 창자겹침증에서는 임 상 증상이 비특이적이므로, 태변 막힘, 자발성 장천공, 괴사성 장염 등과 같은 위장관계 합병증을 의심할 만한 임상 증상이 발생할 경우 반드시 창자겹침증도 함께 고려하는 것이 조기 진단을 위해 무엇보 다 중요한 것으로 판단된다.

\section{ARTICLE INFORMATION}

\section{Ethical statement}

This study was approved by the Institutional Review Board of Ulsan University Hospital (IRB No. 2020-05-004). Informed consent was waived by the board.

\section{Conflicts of interest}

No potential conflict of interest relevant to this article was reported.

\section{Author contributions}

Conception or design: G.L., E.H.H., K.W.O., M.J.C. 
Acquisition, analysis, or interpretation of data: Y.A., G.L., K.W.O., M.J.C.

Drafting the work or revising: Y.A., K.W.O.

Final approval of the manuscript: K.W.O.

\section{ORCID}

Yong-gi Ahn https://orcid.org/0000-0001-9530-1911

Ki Won Oh https://orcid.org/0000-0002-2295-1902

\section{Acknowledgments}

None

\section{REFERENCES}

1. Maqbool A, Liacouras CA. Ileus, adhesions, intussusception, and closed-loop obstructions. In: Kliegman RM, editor. Nelson textbook of pediatrics. 21st ed. Elsevier, 2020:1965-7.

2. Rachelson MH, Jernigan JP, Jackson WF. Intussusception in the newborn infant with spontaneous expulsion of the intussusceptum; a case report and review of the literature. J Pediatr 1955;47: 87-94.

3. Wang NL, Yeh ML, Chang PY, Sheu JC, Chen CC, Lee HC, et al. Prenatal and neonatal intussusception. Pediatr Surg Int 1998;13: 232-6.

4. Ueki I, Nakashima E, Kumagai M, Tananari Y, Kimura A, Fukuda $\mathrm{S}$, et al. Intussusception in neonates: analysis of 14 Japanese patients. J Paediatr Child Health 2004;40:388-91.

5. Patriquin HB, Afshani E, Effman E, Griscom T, Johnson F, Kramer SS, et al. Neonatal intussusception. Report of 12 cases. Radiology 1977;125:463-6.

6. Lee BY, Kim YH, Hwang JB, Kim CS, Lee SL, Kwon TC, et al. A case of ileao-ileal intrauterine intussusception in a preterm neonate. Korean J Pediatr Gastroenterol Nutr 2005;8:247-51.

7. Hong J. Ileal Atresia due to intrauterine intussusception. J Korean Surg Soc 1997;52:732-7.

8. Huang WC, Wang CH, Yuh YS, Chen $\mathrm{YH}$, Chu CC. A rare type of ileal atresia due to intrauterine intussusception. Eur J Pediatr 2007;166:1177-8.

9. Imai Y, Nishijima E, Muraji T, Hashimoto K, Hayashi Y, Itoh H. Fusion of intussusceptum and intussuscipiens in intrauterine intussusception: a rare type of intestinal atresia. Pathol Int 1999; 49:962-7.

10. Kim SC, Kim DY, Kim SY, Kim IK, Kim IS, Kim JE, et al. Intestinal atresia: the second national survey. J Korean Assoc Pediatr Surg 2010;16:1-10.

11. Martinez Biarge M, Garcia-Alix A, Luisa del Hoyo M, Alarcon A, Saenz de Pipaon M, Hernandez F, et al. Intussusception in a preterm neonate: a very rare, major intestinal problem. Systematic review of cases. J Perinat Med 2004;32:190-4.

12. Avansino JR, Bjerke S, Hendrickson M, Stelzner M, Sawin R. Clinical features and treatment outcome of intussusception in premature neonates. J Pediatr Surg 2003;38:1818-21.

13. Nock ML, Wilson-Costello D. Intussusception in a premature neonate. Clin Pediatr (Phila) 2002;41:721-4.

14. Gorgen-Pauly U, Schultz C, Kohl M, Sigge W, Moller J, Gortner L. Intussusception in preterm infants: case report and literature review. Eur J Pediatr 1999;158:830-2.

15. Mooney DP, Steinthorsson G, Shorter NA. Perinatal intussuscep tion in premature infants. J Pediatr Surg 1996;31:695-7.

16. Prakash A, Doshi B, Singh S, Vyas T, Jain A. Intussusception in a premature neonate: a rare and often misdiagnosed clinical entity. Afr J Paediatr Surg 2015;12:82-5.

17. Taskinlar H, Gundogdu G, CelikY, Avlan D, Nayci A. Challenging diagnosis between intussusception and necrotizing enterocolitis in premature infants. Pediatr Int 2014;56:e1-3.

18. Park JY, Kim YG, Lee NM, Cha SJ. Double intussusceptions with necrotizing enterocolitis diagnosed in a premature infant. Neonatal Med 2015;22:213-6.

19. Yoo RP, Touloukian RJ. Intussusception in the newborn: a unique clinical entity. J Pediatr Surg 1974;9:495-8.

20. Shad J, Biswas R. Ileo-colic intussusception in premature neonate. BMJ Case Rep 2011;2011:bcr1120115109.

21. Slam KD, Teitelbaum DH. Multiple sequential intussusceptions causing bowel obstruction in a preterm neonate. J Pediatr Surg 2007;42:1279-81.

22. Siddiqui MM, Drewett M, Burge DM. Meconium obstruction of prematurity. Arch Dis Child Fetal Neonatal Ed 2012;97:F147-50.

23. Kim YJ, Kim EK, Kim ES, Kim HS, Choi JH, Cheon JE, et al. Recognition, diagnosis and treatment of meconium obstruction in extremely low birth weight infants. Neonatology 2012;101:172-8.

24. Starshak RJ, Sty JR, Bruce JS. Meconium plug syndrome associated with neonatal intussusception. Gastrointest Radiol 1981; 6:75-8.

25. Takai A, Hasegawa T, Furukawa T, Tajiri T, Hosoi H. Ultrasonographic findings of multiple intussusception in an extremely preterm infant. Arch Dis Child 2019;104:488.

26. Aydin E. Intussusception in a preterm newborn. Pediatr Neonatol 2018;59:312-4.

27. Raza HA, Basamad MS, El Komy MS, Al Maghrabi A, Habbach $\mathrm{H}$, Abokrecha AY. Diagnosing intussusception in preterm neonates: case report and overview. J Clin Neonatol 2014;3:103-5.

28. Wang Q, Luo M, Xie X, Wu Y, Xiang B. Can intussusceptions of small bowel and colon be transient? A prospective study. Eur J Pediatr 2019;178:1537-44.

29. Kim JH. US features of transient small bowel intussusception in pediatric patients. Korean J Radiol 2004;5:178-84. 